\title{
Effect of using Various Combinations of the Plant Meal as a Source of Vegetable Protein in the Diets of Broiler Chickens in the Productive Performance
}

\author{
Jabbar . T. A. Al- Ali \\ College of Health and Medical Technology - Basra / Southern Technical University, Iraq
}

\begin{abstract}
This study aimed to know the effect of using various combinations of plant meal as a source of vegetable protein in the diets on the productive performance of broilers. A total (150) unsexed broiler chicks (Ross 308) one day old was used in this study. These chicks were randomly distributed to five treatments with 3 replicates each (10 chicks per replicate), The treatments included the use of soybean meal (SBM) as a source of vegetable protein. SBM level in $1^{\text {st }}$ treatment was $24 \%$ in starter diet and $20 \%$ in finisher diet. Its level was $12 \%$ with $12 \%$ of sunflower meal (SFM) in the $2^{\text {nd }}$ treatment in starter diet or $10 \%$ to each of them in finisher diet. Third treatment included 12\% SBM and 12\% sesame meal (SM) of starter diet and $10 \%$ to each of them in finisher diet. Fourth treatment included 12\% from SFM and 12\% SM for starter diet and $10 \%$ to each of them in finisher diet. Fifth treatment contain $8 \%$ from each SBM and SFM and SM for starter diet and 7\% to each of them for finisher diet. The results of the statistical analysis of the experiment data showed. Significant superiority $(P<0.05)$ in the mean of weight of birds of experimental treatments $\left(T_{3}, T_{4}\right.$ and $\left.T_{5}\right)$ in comparison with those of control group $\left(T_{1}\right)$ at age 4 and 6 weeks, where amounted $(2439.2442,2448,2420) \mathrm{g}$, respectively. Were also a Significant increase $(P<0.05)$ in the rates of the weight gain of birds of $\left(T_{3}, T_{4}\right.$ and $\left.T_{5}\right)$ in comparison with the rate of weight gain to the birds of the control treatment $\left(T_{1}\right)$ during $(0$ - 6) week that amounted $(2400,2403,2409,2381)$ g, respectively. Live body weight and growth rate of birds in $\left(T_{2}\right)$ were similar to those of control. Birds of $\left(T_{2}, T_{3}, T_{4}\right.$ and $\left.T_{5}\right)$ were similar to those of control in the rates of feed intake and feed conversion efficiency during different ages. Absence of significant differences in the percentages of mortality in different nutritional groups. Relative weight of chest and thighs of treated birds exceeded those of control group significantly.
\end{abstract}

Keywords: sources of vegetable protein, broiler chickens, productivity

\section{Introduction}

Many of the world's population, particularly the people in developing countries suffer from a severe shortage of food, especially in the protein sources because of the continual increase in their numbers, and shortages of food sources for several reasons. There for to insurance the food to meet the needs of the population, particularly the animal products, makes the search for sources of animal protein with minimum of difficulties and minimum of possible cost is vital matter [29] In order to achieve to this must be interest in the sources of animal protein such as the farming animals and the poultry. The poultry are characteristic by high production efficiency, where the specialists in poultry science enables from getting strains of poultry are characterized by high production of eggs and meat, and these high efficiency in poultry production in many countries of the world ,impute to supplies abundant and good combinations of nutrients in poultry diets, as well as due to the considerable efforts which grant in applied researches in various fields of the poultry industry, particularly in the researches of nutrition science [9]. Since several decades, poultry nutritionist recommend appropriate combinations of nutrients to produce an economical and highly efficient diets ,can be adopted in different ages and production phases of poultry [3] .

Soybean meal (SBM) consider one of the most common sources of vegetable protein in poultry diets [42]. It characterized by a good nutritional value in terms of protein content $45 \%$ or more with good biological value [6].This protein contains on essential amino acids need by birds . Soybean meal content of crude protein ( 44\%) with good proportions of amino acid amounted (1.17\% Lysine, $0.61 \%$,Mehionine, $1.31 \%$ Cystine, $0.61 \%$ Tryptophan, 3.42\% for Leucine [40].

As a result of the expansion that took place in poultry industry , the request on the SBM has become continuously growing. As well as cultivation and production of soybeans, is limited to few countries around the world, increases their prices especially feeds cost, comprises $65-70 \%$ of total expenses [39]. Alternative sources of proteins from local plants may reduce the crisis in case these plants have similar type of protein as that of SBM, [10]. One of these alternatives that can be used in poultry diets and being available locally are the remnants of vegetable oils industry such as sunflower meal and sesame meal after some alteration [2].

Sunflower meal resulting from shelled seeds contains $(40 \%)$ crude protein, with essential amino acids, and rich in mineral elements and vitamins, especially Vitamin B complex [17]. Chemical composition of the SFM depend on the type of seeds and the method of preparation, as well as the way of oil extraction [34]. Sunflower meal contain (43 - $50 \%)$ crude protein of good nutritional value $[19 ; 21 ; 23]$.

Many studies were conducted been to find out the possibility of the benefiting from sunflower meal as a source of vegetable protein in poultry diets .The study of [37]. pointed out the possibility of using sunflower meal successfully in the diets of laying hens when balancing the level of amino acid( Lysine) and energy in the diets. Study of [1], discuss the possibility of using sunflower meal instead of soybean meal in the diets of broiler chickens ,because it's contain a good ratio of protein, especially the meal which resulting from shelled seeds, in addition to the good content from amino acids is which meets

Volume 6 Issue 1, January 2017 


\section{International Journal of Science and Research (IJSR) \\ ISSN (Online): 2319-7064}

Index Copernicus Value (2015): 78.96 | Impact Factor (2015): 6.391

the needs of the birds except (Lysine), in comparison with soybean meal. When broiler fed diets containing 35\% sunflower meal as a source of vegetable protein improved the productive performance [25]. Replacing (30\%) of soybean meal by sunflower meal in the diets did not have any detrimental effect on the productive performance of broilers [18]. A significant improvement $(\mathrm{P}<0.05)$ in the productive performance of broiler chickens when fed sunflower meal in the starter diets of broiler at rate of (28$30 \%$ ) [35]. There was a possibility of using sunflower meal in the diets of laying hens by up to $12 \%$ without affected the productive performance of chickens [14].

Another vegetable protein source is sesame seeds meal. This crop is produced in many countries of the world by good quantities; it's an oil crop with high ratio of protein reaches more than $30 \%$ with moderate fiber $7 \%$, [26]. The composition of the amino acids in sesame protein is similar to the composition of the amino acids in soy protein except the amino acid (Lysine) which is found at a low ratio. It can be added to the diets to meet the requirements of the birds $[22 . ; 30]$. The meal produced from sesame seeds do not easily oxidized or rancidity, because this meal contain on certain substances such as (Sesamol, Sesamoline, $\alpha$ - Tocopherol), which consider of the anti-oxidants [38]. Sesame seeds meal contain (42.5\%) crude protein [24] . Chemical composition of sesame seeds were (moisture $4.6 \%$, ash $3.3 \%$, fiber $7.2 \%$, oil $55.5 \%$,protein $23 \%$ and carbohydrate $13.6 \%$ ) [36] .

There is an ability to replace the sesame meal instead of soybean meal in the diets of laying hens by ratios $(25 \%$, $50 \%, 75 \%$ ) resulting no significant differences in weight gain, egg production and feed intake among the treatments replacement of ( $50 \%$ and $25 \%$ ) and control treatment which used soybean meal [15].

Therefore, this study aimed to know the effect of different combinations of sources of vegetable protein in the productive performance of broiler chickens

\section{Materials and Methods}

This experiment was conducted in one of private broiler chickens field, A total of 150 unsexed chicks (Ross) one day old weighted $39 \mathrm{gm}$ were randomly distributed to five treatment with 3 replicates ( 10 chicks per replicated). The chicks were fed adlibtun along the duration of the experiment ,starter feed was given from the first day until 21 days then it was replace by finisher diet at the age of 22 days up to the end of the treated period. Diets in the treatments are as follows.

The treatments included the use of soybean meal (SBM) as a source of vegetable protein. SBM level in $1^{\text {st }}$ treatment was $24 \%$ in starter diet and $20 \%$ in finisher diet. Its level was $12 \%$ with $12 \%$ of sunflower meal (SFM) in the $2^{\text {nd }}$ treatment in starter diet or $10 \%$ to each of them in finisher diet. Third treatment included 12\% SBM and 12\% sesame meal (SM) of starter diet and $10 \%$ to each of them in finisher diet. Fourth treatment included 12\% from SFM and $12 \% \mathrm{SM}$ for starter diet and $10 \%$ to each of them in finisher diet. Fifth treatment contain $8 \%$ from each SBM and SFM and SM for starter diet and 7\% to each of them for finisher diet

(Table 1 and 2).

Sunflower meal was prepared by buying seeds from the local market cleaned them from all impurities completely, peel them manually, grind the peeled seed by using electric grinder and extracted the oil from the grind seeds, by soaking in hexane for 24 hours. Dry the crushed grain by leaving in the air for five hours to get rid of hexane. Grind the crushed grain to get meal. The meal were kept the in polyethylene bags and stored in refrigeration until use.

The sesame meal was obtained from one of contemporary to manufacturing the briber, placed in polyethylene bags and stored in refrigeration until use.

The chemical analysis to the samples of sunflower meal and sesame meal, as well as samples of the diets were conducted according to [12] .

Productive performance represented by live body weight, weighted the chicks of day-old and then weekly. Weight gain was calculated by the following equation

(The weight at the end of the week - the weight at the beginning of the week). Feed intake per week was calculated by the following equation the Rate of feed intake (g/ bird) = The amount of feed provided beginning of the week - the amount of residual forage in weekend [27]

Feed consumption was calculated according to the following equation daily average of the consumer fodder $(\mathrm{g} / \mathrm{bird})=$ the feed intake during the week / number of live birds in weekend $\times 7 \times$ number of days in which fed the mortality birds [27.; 5]

The Feed Conversion Efficiency was calculated according to the following equation:

Feed Conversion Efficiency= the feed intake during a certain period to one bird / rate of weight gain during the same period. [28]

The Mortality Ratio calculated, as a percentage, according to the following equation:

Mortality Ratio $=[$ number of mortality birds in each treatment / total number of birds in treatment] $\times 100$ [11]

The Production Index was calculated according to the following equation.

Production Index $=$ [average of body weight $(\mathrm{g}) \times$ vital ratio $] /$ [number of breeding days $\times$ feed conversion efficiency $\times 10$ Vital Ratio $=100-$ Mortality Ratio . [28]

The Dressing percentage was calculated on the basis of cold carcass weight with edible internal organs . Relative weights of carcass parts was measured by using a sensitive balance , [5]

Randomized complete design ( CRD) was used to study the effect of using various combinations of vegetable protein in 


\section{International Journal of Science and Research (IJSR) \\ ISSN (Online): 2319-7064 \\ Index Copernicus Value (2015): 78.96 | Impact Factor (2015): 6.391}

diets by using [41]. The Significant differences between the means was tested by using [16].

Table 1: Chemical composition of sunflower and sesame meals

\begin{tabular}{|l|c|c|c|c|c|c|c|}
\hline \multirow{2}{*}{ Feed } & \multicolumn{6}{|c|}{ Percentages of the components of material } \\
\cline { 2 - 8 } & DM & Moisture & Protein & Fat & Fiber & Ash & Met-energy kcal/Kg \\
\hline Sunflower meal(SFM) & 94 & 6 & 45 & 2.9 & 13.6 & 4.32 & 2320 \\
\hline Sesame meal (SM) & 92 & 8 & 46 & 4.9 & 14 & 11 & 2531 \\
\hline
\end{tabular}

Table 2: The starter diets components

\begin{tabular}{|c|c|c|c|c|c|}
\hline \multirow{2}{*}{ Diets components } & \multicolumn{6}{|c|}{$\begin{array}{c}\text { Treatments and proportions of forage } \\
\text { ingredients in each treatment }\end{array}$} \\
\cline { 2 - 6 } & $\mathrm{T}_{1}$ & $\mathrm{~T}_{2}$ & $\mathrm{~T}_{3}$ & $\mathrm{~T}_{4}$ & $\mathrm{~T}_{5}$ \\
\hline yellow corn & 55 & 55 & 55 & 55 & 55 \\
\hline Wheat & 10 & 10 & 10 & 10 & 10 \\
\hline Soybean meal (SBM) & 24 & 12 & 12 & - & 8 \\
\hline Sunflower meal (SFM) & - & 12 & - & 12 & 8 \\
\hline Sesame meal (SM) & - & - & 12 & 12 & 8 \\
\hline $\begin{array}{c}\text { protein concentrate 50 } \\
\text { \% protein }\end{array}$ & 10 & 10 & 10 & 10 & 10 \\
\hline Limestone & 0.7 & 0.7 & 0.7 & 0.7 & 0.7 \\
\hline Salt & 0.3 & 0.3 & 0.3 & 0.3 & 0.3 \\
\hline Total & $\% 100$ & $100 \%$ & $\% 100$ & $\% 100$ & $\% 100$ \\
\hline Chemical composition of the diets & \\
\hline Nutrients & $\mathrm{T}_{1}$ & $\mathrm{~T}_{2}$ & $\mathrm{~T}_{3}$ & $\mathrm{~T}_{4}$ & $\mathrm{~T}_{5}$ \\
\hline Energy kcal / kg & 2939 & 2950 & 2975 & 2985 & 2970 \\
\hline Crude protein\% & 21.2 & 21.23 & 21.35 & 21.47 & 21.35 \\
\hline Crude fiber\% & 3.44 & 4.23 & 4.28 & 5.08 & 4.42 \\
\hline Energy ratio: protein & 138.6 & 138.9 & 139.3 & 139 & 139.1 \\
\hline
\end{tabular}

$\mathrm{T}_{1}=24 \% \mathrm{SBM}$ control. $\mathrm{T}_{2}=12 \% \mathrm{SBM}+12 \% \mathrm{SFM} . \mathrm{T}_{3}$ $=12 \% \mathrm{SBM}+12 \% \mathrm{SM} . \mathrm{T}_{4}=12 \% \mathrm{SFM}+12 \% \mathrm{SM} . \mathrm{T}_{5}$ $=8 \% \mathrm{SBM}+8 \% \mathrm{SFM}+8 \% \mathrm{SM}$.

Table 3: The finisher diets components

\begin{tabular}{|c|c|c|c|c|c|}
\hline \multirow{2}{*}{ Diets components } & \multicolumn{5}{|c|}{$\begin{array}{c}\text { Treatments and proportions of forage } \\
\text { ingredients in each treatment }\end{array}$} \\
\cline { 2 - 6 } & $\mathrm{T}_{1}$ & $\mathrm{~T}_{2}$ & $\mathrm{~T}_{3}$ & $\mathrm{~T}_{4}$ & $\mathrm{~T}_{5}$ \\
\hline yellow corn & 55 & 55 & 55 & 55 & 55 \\
\hline Wheat & 10 & 10 & 10 & 10 & 10 \\
\hline $\begin{array}{c}\text { Soybean meal } \\
\text { (SBM) }\end{array}$ & 20 & 10 & 10 & - & 7 \\
\hline $\begin{array}{c}\text { Sunflower mea } \\
\text { l(SFM) }\end{array}$ & - & 10 & - & 10 & 7 \\
\hline Sesame meal (SM) & - & - & 10 & 10 & 7 \\
\hline $\begin{array}{c}\text { protein concentrate } \\
50 \% \text { protein }\end{array}$ & 10 & 10 & 10 & 10 & 10 \\
\hline Vegetable oil & 4 & 4 & 4 & 4 & 3 \\
\hline Limestone & 0.7 & 0.7 & 0.7 & 0.7 & 0.7 \\
\hline Salt & 0.3 & 0.3 & 0.3 & 0.3 & 0.3 \\
\hline Total & $\% 100$ & $\% 100$ & $\% 100$ & $\% 100$ & $\% 100$ \\
\hline \multicolumn{7}{c|}{ Chemical composition of the diets } \\
\hline Nutrients & $\mathrm{T}_{1}$ & $\mathrm{~T}_{2}$ & $\mathrm{~T}_{3}$ & $\mathrm{~T}_{4}$ & $\mathrm{~T}_{5}$ \\
\hline Energy kcal / kg & 3202 & 3211 & 3232 & 3241 & 3164 \\
\hline Crude protein\% & 19.35 & 19.45 & 19.56 & 19.65 & 20 \\
\hline Crude fiber\% & 3.16 & 3.66 & 4.18 & 4,67 & 4.28 \\
\hline $\begin{array}{c}\text { Energy ratio: } \\
\text { protein }\end{array}$ & 165.47 & 165.08 & 165.27 & 164.9 & 158.2 \\
\hline
\end{tabular}

$\mathrm{T}_{1}=20 \%$ SBM control . $\mathrm{T}_{2}=10 \% \mathrm{SBM}+10 \% \mathrm{SFM} . \mathrm{T}_{3}$ $=10 \% \mathrm{SBM}+10 \% \mathrm{SM} . \mathrm{T}_{4}=10 \% \mathrm{SFM}+10 \% \mathrm{SM} . \mathrm{T}_{5}$ $=7 \% \mathrm{SBM}+7 \% \mathrm{SFM}+7 \% \mathrm{SM}$.

\section{Results and Discussion}

A mean body weights at $2,4,6$ weeks of different treatments are shown in table (4) .Body weights of different treatments at 2 weeks of age were similar with no significant difference. However at 4 weeks of age, birds of fifth treatment $\left(\mathrm{T}_{5}, 8 \%\right.$ from all vegetable meals used at starter and $7 \%$ at finisher ) showed heavier $(\mathrm{P}<0.05)$ weight in comparison with control [ 1393 vs 1372 g respectively). At 6 weeks of age birds of treatments 3,4 and 5 showed superior $(\mathrm{P}<0.05)$ weights in comparison with that of control group (2439, 2442, 2448 and 2420 respectively).

The result of this study agree with the study result of [4], where he found a significant superiority of live body weight of broiler ( Hubbard ) that fed diets contain remnants of briber industry by ratios $(0,3.5,7,10.5$ and 14$) \%$ in the starter diets, and by ratios of $(0,3,6,9$ and 12$) \%$ in the growth diets . Reason behind this superiority was the level of oil of sesame and sunflower meals. Therefore birds get all their requirements from energy to maintain their bodies and this gives the birds a chance to exploit the available protein in the feed to build body tissues and growth, [20]. The reason may also be due to active compounds found in sesame seeds meal such as (Sesamol, Sesamoline, $\alpha$ - Tocopherol), which are consider of antioxidants these active substances which present in some medical plants and oils prevent oxidation of the body's cells and protects the body tissues from peroxides and prevent the demolition of protein in the body which gives the body the best chance to take advantage of the protein in the construction of cells and thus increase weight, [13]. As well as sunflower meal, which is considered a rich source of protein and are free from any growth inhibitor, may reflected on the improvement of the level of birds growth. It can be note from the table , there were no significant difference in the live body weight at 6 weeks of age of $\left(\mathrm{T}_{2}\right),(12$ SBM $\%+12 \%$ SFM $)$ in starter stage and $(10 \mathrm{SBM} \%+10 \% \mathrm{SFM})$ in finisher stage and control treatment $(24 \% \mathrm{SBM})$ in starter stage and $(20 \% \mathrm{SBM})$ in finisher stage. There were no significant differences $(\mathrm{P}<0.05)$ in live body weight of treatments $\left(\mathrm{T}_{2}, \mathrm{~T}_{3}, \mathrm{~T}_{4}, \mathrm{~T}_{5}\right)$ at 6 weeks of age .

Table 4: The impact of the use of various combinations of vegetable protein sources in broiler chickens diets on life body weight $(\mathrm{g})$, through various ages

\begin{tabular}{|c|c|c|c|}
\hline \multirow{2}{*}{ Treatments } & \multicolumn{3}{|c|}{$\begin{array}{c}\text { Life body weight through the various ages } \\
\text { (mean } \pm \text { standard error) }\end{array}$} \\
\cline { 2 - 4 } & 2 & 4 & 6 \\
\hline $\mathrm{T}_{1}$ & $400 \pm 6.928$ & $1372^{\mathrm{b}} \pm 3.605$ & $2420^{\mathrm{b}} \pm 6.11$ \\
\hline $\mathrm{T}_{2}$ & $406 \pm 2.081$ & $1381^{\mathrm{ab}} \pm 7.095$ & $2431^{\mathrm{ab}} \pm 2.64$ \\
\hline $\mathrm{T}_{3}$ & $411 \pm 6.658$ & $1387^{\mathrm{ab}} \pm 7.371$ & $2439^{\mathrm{a}} \pm 6.24$ \\
\hline $\mathrm{T}_{4}$ & $415 \pm 7.094$ & $1389^{\mathrm{ab}} \pm 6.657$ & $2442^{\mathrm{a}} \pm 5.68$ \\
\hline $\mathrm{T}_{5}$ & $417 \pm 8.000$ & $1393^{\mathrm{a}} \pm 4.725$ & $2448^{\mathrm{a}} \pm 4.37$ \\
\hline Significant & N.S & $*$ & $*$ \\
\hline
\end{tabular}

* Vertically different letters indicate a significant difference (P $<0.05)$ between the mean of treatments . N.S refers to the absence of significant differences $(\mathrm{P}<0.05)$ between the mean of treatments.

$\mathrm{T}_{1}$ control treatment (24\% SBM). $\mathrm{T}_{2}(12 \% \mathrm{SBM}+12 \% \mathrm{SFM})$. $\mathrm{T}_{3}(12 \% \mathrm{SBM}+12 \% \mathrm{SM}) . \mathrm{T}_{4}(12 \% \mathrm{SFM}+12 \% \mathrm{SM}) . \mathrm{T}_{5}(8 \%$ $\mathrm{SBM}+8 \% \mathrm{SFM}+8 \% \mathrm{SM})$. 


\section{International Journal of Science and Research (IJSR) \\ ISSN (Online): 2319-7064 \\ Index Copernicus Value (2015): 78.96 | Impact Factor (2015): 6.391}

It is clear from Table (5) there were no significant differences in rates of the weight gain among treatments and the control group during periods $(0-2,2-4,4-6)$ Week . However, significant differences $(\mathrm{P}<0.05)$ in weight gain rates during the period $(0-6)$ week between the experimental treatments $\left(\mathrm{T}_{3}, \mathrm{~T}_{4}\right.$ and $\left.\mathrm{T}_{5}\right),(2400,2403$, 2409) $\mathrm{g}$, respectively, and control treatment (2381) $\mathrm{g}$. The result of the present study agreed with the results of the study of [8]. Who indicated significant superiority in the rate of weight gain of the birds that were fed on diet containing $(16 \%)$ of the briber waste of $5 \%$ and $24 \%$ SBM . The result of this study also agree with the result of [7] who found a significant superiority $(\mathrm{P}<0.05)$ in the rate of weight gain for rabbits fed diet contain (SM $16 \%$ ) in comparison to the rates of weight gain in the control treatment rabbits $(0 \% \mathrm{SM})$. While there was no significant difference $(\mathrm{P}<0.05)$ in the rate of weight gain between the second treatment $\left(\mathrm{T}_{2}\right),(12 \% \mathrm{SBM}+12 \% \mathrm{SFM})$ in starter stage and $(10 \% \mathrm{SBM}+10 \% \mathrm{SFM})$ in finisher stage and the control $(24 \% \mathrm{SBM})$ in starter stage and $(20 \% \mathrm{SBM})$ in finisher stage.

Improvement in live body weight gain of birds of these treatments during all breeding period was a reflection of live body weight improvement resulted from adding sesame meal, sunflower meal and soybean meal is a combination of vegetable protein sources enabled the birds to obtain their requirements from protein and necessary amino acids for good growth. The other reason of the superiority of these treatments could be the balance of amino acids o the protein of these treatments.

Table 5: The impact of various combinations of vegetable protein sources in broiler chickens diets on weight gain

(g), through the various ages

\begin{tabular}{|c|c|c|c|c|}
\hline \multirow{2}{*}{ Treatments } & \multicolumn{4}{|c|}{$\begin{array}{c}\text { Weight gain through the various ages (week) } \\
\text { (mean } \pm \text { standard error) }\end{array}$} \\
\cline { 2 - 5 } & $0-2$ & $2-4$ & $4-6$ & $0-6$ \\
\hline $\mathrm{T}_{1}$ & $361 \pm$ & $972 \pm$ & $1048 \pm 3.785$ & $2381^{\mathrm{b}} \pm 7.110$ \\
& 6.426 & 3.610 & & \\
\hline $\mathrm{T}_{2}$ & $367 \pm$ & $975 \pm$ & $1050 \pm 4.509$ & $2392^{\mathrm{ab}} \pm 2.884$ \\
& 3.061 & 6.557 & & \\
\hline $\mathrm{T}_{3}$ & $372 \pm$ & $976 \pm$ & $1052 \pm 4.163$ & $2400^{\mathrm{a}} \pm 8.245$ \\
& 6.551 & 1.157 & & \\
\hline $\mathrm{T}_{4}$ & $376 \pm$ & $974 \pm$ & $1053 \pm 1.527$ & $2403^{\mathrm{a}} \pm 5.888$ \\
& 7.104 & 2.002 & & \\
\hline $\mathrm{T}_{5}$ & $378 \pm$ & $976 \pm$ & $1055 \pm 2.516$ & $2409^{\mathrm{a}} \pm 5.440$ \\
& 4.618 & 1.393 & & $*$ \\
\hline significant & N.S & N.S & N.S & $*$ \\
\hline
\end{tabular}

* Vertically different letters indicate a significant difference $(\mathrm{P}<0.05)$ between the mean of treatments . N.S refers to the absence of significant differences $(\mathrm{P}<0.05)$ between the mean of treatments.

$\mathrm{T}_{1}$ control treatment $(24 \% \mathrm{SBM}) . \mathrm{T}_{2}(12 \% \mathrm{SBM}+12 \%$ SFM). $\mathrm{T}_{3}(12 \% \mathrm{SBM}+12 \% \mathrm{SM}) . \mathrm{T}_{4}(12 \% \mathrm{SFM}+12 \%$ $\mathrm{SM})$.

$\mathrm{T}_{5}(8 \% \mathrm{SBM}+8 \% \mathrm{SFM}+8 \% \mathrm{SM})$ in starter stage and $\mathrm{T}_{1}(20 \% \mathrm{SBM}), \mathrm{T}_{2}(10 \% \mathrm{SBM}+10 \% \mathrm{SFM}) . \mathrm{T}_{3}(10 \%$ $\mathrm{SBM}+10 \% \mathrm{SM}), \mathrm{T}_{4}(10 \% \mathrm{SFM}+10 \% \mathrm{SM})$ and $\mathrm{T}_{5}(7 \%$ $\mathrm{SBM}+7 \% \mathrm{SFM}+7 \% \mathrm{SM})$ in finisher stage.

Table 6 , shows the rates of feed consumption ( $\mathrm{g} \backslash$ bird) during the different age periods. The results of analysis of variance showed no significant differences at the level of the probability $(\mathrm{P}<0.05)$ between different treatments through the stages. The results of this study conform with the results of [31] that the addition of sunflower meal to the diets of broiler chickens by rates $(0,4,8,12 \%)$ had no significant effect on feed intake during the period (3 - 42) days. Also it's consistent with the study results of [4] who use briber waste in the diets of broiler chickens during the growing phase with ratios $(0,3$, 6,9 and $12 \%$ ). The results of our study were in contrary to the study results of [7] who noted a significant decrease in feed intake when using the sesame meal in the diets of rabbits with rates of $(8,16) \%$ with increase the addition ratio from sesame meal in diet.

Table 6: The impact of use of various combinations of vegetable protein sources in diets of broiler chickens on the amount of feed intake rates ( $\mathrm{g} /$ bird) through various ages (mean \pm standard error)

\begin{tabular}{|c|c|c|c|c|}
\hline \multirow{2}{*}{ Treatments } & \multicolumn{4}{|c|}{ Feed intake (g / bird) through the various ages (week) } \\
& \multicolumn{4}{|c|}{ (mean \pm standard error) } \\
\cline { 2 - 5 } & $0-2$ & $2-4$ & $4-6$ & $6-0$ \\
\hline $\mathrm{T}_{1}$ & $482 \pm 5.196$ & $1287 \pm 3.214$ & $2246 \pm 4.096$ & $4003 \pm 7.816$ \\
\hline $\mathrm{T}_{2}$ & $484 \pm 2.886$ & $1276 \pm 2.081$ & $2245 \pm 2.309$ & $4008 \pm 2.645$ \\
\hline $\mathrm{T}_{3}$ & $489 \pm 6.245$ & $1284 \pm 7.371$ & $2252 \pm 7.767$ & $4025 \pm 19.078$ \\
\hline $\mathrm{T}_{4}$ & $494 \pm 2.081$ & $1286 \pm 3.511$ & $2259 \pm 4.725$ & $4033 \pm 3.785$ \\
\hline $\mathrm{T}_{5}$ & $498 \pm 6.806$ & $1290 \pm 3.214$ & $2261 \pm 4.932$ & $4035 \pm 2.886$ \\
\hline Significant & $\mathrm{N} . \mathrm{S}$ & N.S & N.S & N.S \\
\hline
\end{tabular}

N.S refers to the absence of significant differences $(\mathrm{P}<0.05)$ between the mean of treatments.

$\mathrm{T}_{1}$ control treatment (24\% SBM). $\mathrm{T}_{2}(12 \% \mathrm{SBM}+12 \% \mathrm{SFM})$. $\mathrm{T}_{3}(12 \% \mathrm{SBM}+12 \% \mathrm{SM}) . \mathrm{T}_{4}(12 \% \mathrm{SFM}+12 \% \mathrm{SM}) . \mathrm{T}_{5}(8 \%$ $\mathrm{SBM}+8 \% \mathrm{SFM}+8 \% \mathrm{SM})$ in starter stage and $\mathrm{T}_{1}(20 \% \mathrm{SBM})$ , $\mathrm{T}_{2}(10 \% \mathrm{SBM}+10 \% \mathrm{SFM}) . \mathrm{T}_{3}(10 \% \mathrm{SBM}+10 \% \mathrm{SM})$, $\mathrm{T}_{4}(10 \% \mathrm{SFM}+10 \% \mathrm{SM})$ and $\mathrm{T}_{5}(7 \% \mathrm{SBM}+7 \% \mathrm{SFM}+7 \%$ $\mathrm{SM})$ in finisher stage.

Results of the statistical analysis of feed conversion efficiency is shown in the table (7). No found significant differences in feed conversion efficiency between experimental treatments and the control treatment (SBM), through the various ages. The results of our study are consistent with the study results of [32]. They stated that were no significant differences in the rates of feed conversion efficiency of broiler chickens which fed diets with (SM) instead of (SBM) at different rates $(0,33$, $67,100 \%)$. Perhaps the reason for this convergence is due to an increase in efficiency of digestive system of birds.

Table 7: Effect of using various combinations of vegetable protein sources in diets of broiler chickens on feed conversion efficiency, during various ages

(mean \pm standard error)

\begin{tabular}{|c|c|c|c|c|}
\hline \multirow{2}{*}{} & \multicolumn{4}{|c|}{ feed conversion efficiency (feed g / weight gain $\mathrm{g}$ ), } \\
& $0-2$ week & $2-4$ & $4-6$ & $0-6$ \\
\cline { 2 - 5 } & $0-6$ thing the various ages (mean \pm standard error) \\
\hline $\mathrm{T}_{1}$ & $1.335 \pm$ & $1.315 \pm$ & $2.134 \pm$ & $1.680 \pm$ \\
& 0.011 & 0.003 & 0.004 & 0.003 \\
\hline $\mathrm{T}_{2}$ & $1.318 \pm$ & $1.308 \pm$ & $2.137 \pm$ & $1.675 \pm$ \\
& 0.006 & 0.006 & 0.007 & 0.001 \\
\hline $\mathrm{T}_{3}$ & $1.314 \pm$ & $1.315 \pm$ & $2.140 \pm$ & $1.676 \pm$ \\
& 0.007 & 0.006 & 0.007 & 0.006 \\
\hline $\mathrm{T}_{4}$ & $1.314 \pm$ & $1.319 \pm$ & $2.144 \pm$ & $1.677 \pm$ \\
& 0.021 & 0.001 & 0.004 & 0.005 \\
\hline $\mathrm{T}_{5}$ & $1.316 \pm$ & $1.321 \pm$ & $2.142 \pm$ & $1.711 \pm$ \\
& 0.004 & 0.004 & 0.009 & 0.060 \\
\hline significant & N.S & N.S & N.S & N.S \\
\hline
\end{tabular}




\section{International Journal of Science and Research (IJSR) \\ ISSN (Online): 2319-7064 \\ Index Copernicus Value (2015): 78.96 | Impact Factor (2015): 6.391}

N.S - refers to the absence of significant differences (P $<0.05)$ between the mean of treatments .

$\mathrm{T}_{1}$ control treatment $(24 \% \mathrm{SBM}) . \mathrm{T}_{2}(12 \% \mathrm{SBM}+12 \%$ SFM). $\mathrm{T}_{3}(12 \% \mathrm{SBM}+12 \% \mathrm{SM}) . \mathrm{T}_{4}(12 \% \mathrm{SFM}+12 \%$ $\mathrm{SM}) . \mathrm{T}_{5}(8 \% \mathrm{SBM}+8 \% \mathrm{SFM}+8 \% \mathrm{SM})$ in starter stage and $\mathrm{T}_{1}(20 \% \mathrm{SBM}), \mathrm{T}_{2}(10 \% \mathrm{SBM}+10 \% \mathrm{SFM}) . \mathrm{T}_{3}(10 \%$ $\mathrm{SBM}+10 \% \mathrm{SM}), \mathrm{T}_{4}(10 \% \mathrm{SFM}+10 \% \mathrm{SM})$ and $\mathrm{T}_{5}(7 \%$ $\mathrm{SBM}+7 \% \mathrm{SFM}+7 \% \mathrm{SM})$ in finisher stage.

Table 8 shows the results of the statistical analysis of mortality ratio . It is observed decrease in the mortality ratios of all treatments, $(0 \%)$ in the treatments $\left(\mathrm{T}_{1}, \mathrm{~T}_{3}\right.$ and $\left.\mathrm{T}_{5}\right)$ and $(3.33 \%)$ in the second and fourth treatments $\left(\mathrm{T}_{2}\right.$, $\mathrm{T}_{4}$ ). The result of this study has corresponded with the study results of [6]. Their findings showed no significant differences in the percentage of mortality between treatments of plant protein complexes which locally produced in the broiler diets. The reason may be due to the managements procedures taken place in prepare the breeding hall (cleaning and sterilization) in addition to the intensive care of the chicks. As well as vaccination program which has a great role in raising the birds immunity, in addition to activate the immune system against disease.

Table 8: The effect of using various combinations of vegetable protein sources in diets of broiler chickens on the Mortality Ratio

\begin{tabular}{|c|c|}
\hline Treatments & Mortality Ratio $\%$ \\
\hline $\mathrm{T}_{1}$ & 0.00 \\
\hline $\mathrm{T}_{2}$ & 3.33 \\
\hline $\mathrm{T}_{3}$ & 0.00 \\
\hline $\mathrm{T}_{4}$ & 3.33 \\
\hline $\mathrm{T}_{5}$ & 0.00 \\
\hline Significant & N.S \\
\hline
\end{tabular}

N.S: refers to the absence of significant differences (P $<0.05)$ between the mean of treatments.

$\mathrm{T}_{1}$ control treatment $(24 \% \mathrm{SBM}) . \mathrm{T}_{2}(12 \% \mathrm{SBM}+12 \%$ SFM). $\mathrm{T}_{3}(12 \% \mathrm{SBM}+12 \% \mathrm{SM}) . \mathrm{T}_{4}(12 \% \mathrm{SFM}+12 \%$ $\mathrm{SM}) . \mathrm{T}_{5}(8 \% \mathrm{SBM}+8 \% \mathrm{SFM}+8 \% \mathrm{SM})$ in starter stage and $\mathrm{T}_{1}(20 \% \mathrm{SBM}), \mathrm{T}_{2}(10 \% \mathrm{SBM}+10 \% \mathrm{SFM}) . \mathrm{T}_{3}(10 \%$ $\mathrm{SBM}+10 \% \mathrm{SM}), \mathrm{T}_{4}(10 \% \mathrm{SFM}+10 \% \mathrm{SM})$ and $\mathrm{T}_{5}(7 \%$ $\mathrm{SBM}+7 \% \mathrm{SFM}+7 \% \mathrm{SM})$ in finisher stage.

The table (9) shows the impact of the use of different combinations of plant meal in the diets of broiler chickens on the productive index measurement. It was observed from this table there were no significant differences below the level of the probability $(\mathrm{P}<0.05)$ between all the experimental treatments, although there was noted arithmetic superiority to productive index of the fifth treatment $\left(\mathrm{T}_{5}\right)$ However, this superiority did not cause a significant difference, where the measurement of productive Index, $(342,333,346334$ 348) for the treatments $\left(\mathrm{T}_{1}, \mathrm{~T}_{2}, \mathrm{~T}_{3}, \mathrm{~T}_{4}, \mathrm{~T}_{5}\right)$, respectively.

Absence of the significant differences in productive index of the various treatments was due to the decrease of mortality ratio in all treatments, and the absence of significant differences in the mortality ratio among different treatments, as well as to the absence of significant differences in feed conversion efficiency between different treatments. Mortality ratio and feed conversion efficiency are considered as the factors that determine the value of the productive index measurement

Table 9: Impact of the use of various combinations of vegetable protein sources in diets of broiler chickens on the Production Index measurement

\begin{tabular}{|c|c|}
\hline Treatments & PI \\
\hline $\mathrm{T}_{1}$ & $342 \pm 10.122$ \\
\hline $\mathrm{T}_{2}$ & $333 \pm 11.429$ \\
\hline $\mathrm{T}_{3}$ & $346 \pm 4.381$ \\
\hline $\mathrm{T}_{4}$ & $334 \pm 10.386$ \\
\hline $\mathrm{T}_{5}$ & $348 \pm 10.209$ \\
\hline Significant & N.S \\
\hline
\end{tabular}

N.S: refers to the absence of significant differences $(\mathrm{P}<0.05)$ between the mean of treatments .

$\mathrm{T}_{1}$ control treatment $(24 \% \mathrm{SBM}) . \mathrm{T}_{2}(12 \% \mathrm{SBM}+12 \% \mathrm{SFM})$. $\mathrm{T}_{3}(12 \% \mathrm{SBM}+12 \% \mathrm{SM}) . \mathrm{T}_{4}(12 \% \mathrm{SFM}+12 \% \mathrm{SM}) . \mathrm{T}_{5}(8 \%$ $\mathrm{SBM}+8 \% \mathrm{SFM}+8 \% \mathrm{SM})$ in starter stage and $\mathrm{T}_{1}(20 \% \mathrm{SBM})$ , $\mathrm{T}_{2}(10 \% \mathrm{SBM}+10 \% \mathrm{SFM}) . \mathrm{T}_{3}(10 \% \mathrm{SBM}+10 \% \mathrm{SM})$, $\mathrm{T}_{4}(10 \% \mathrm{SFM}+10 \% \mathrm{SM})$ and $\mathrm{T}_{5}(7 \% \mathrm{SBM}+7 \% \mathrm{SFM}+7 \%$ $\mathrm{SM})$ in finisher stage.

It appears from the result of statistical analysis of dressing percent and relative weights to the carcass parts in Table (10) the absence significant differences $(\mathrm{P}<0.05)$ between the experimental treatments and the control. There were significant superiority to the experimental treatments $\left(\mathrm{T}_{3}, \mathrm{~T}_{4}\right.$, $\mathrm{T}_{5}$ ) on the control treatment $\left(\mathrm{T}_{1}\right)$ for chest cut. Their relative weights were $(28.14,28.15,28.15) \%$ of carcass weight, respectively, while the relative weight to the chest cut in the control treatment was $(28.04 \%)$ of carcass weight. It was also noted from the table the significant superiority to the four experimental treatments $\left(\mathrm{T}_{2}, \mathrm{~T}_{3}, \mathrm{~T}_{4}, \mathrm{~T}_{5}\right)$ on the control treatment for the relative weights of the thighs cut, $(32.12$, $32.14,32.16,32.17 \%$ ) of carcass weight in the four treatments, respectively, that of control was $(32.05 \%)$. This result is consistent with the study result of [33] they stated in it that the use of sunflower seeds in the diets of broiler chickens during the two phases of the starter and growth phases at rates of $(0,70,140,210) \mathrm{g} / \mathrm{kg}$ feed, resulted in a significant improvement in the rate of weight gain and relative weights of cut (chest and thighs). There were no significant differences ( $\mathrm{P}$ $<0.05$ ) for the relative weights of back, wings and neck among all treatments. 


\section{International Journal of Science and Research (IJSR) \\ ISSN (Online): 2319-7064}

Index Copernicus Value (2015): 78.96 | Impact Factor (2015): 6.391

Table 10: Effect of using various combinations of vegetable protein sources in diets of broiler chickens on dressing

percentage and relative weights of carcass pieces (mean \pm standard error)

\begin{tabular}{|c|l|c|c|c|c|c|}
\hline \multirow{2}{*}{ treatments } & \multicolumn{5}{|c|}{ Dressing percentage and relative weights of carcass Qtaiat } \\
\cline { 2 - 7 } & Dressing percentage & Chest & Thighs & Back & Wings & neck \\
\hline $\mathrm{T}_{1}$ & $72 \pm 1.154$ & $28.04^{\mathrm{b}} \pm 0.011$ & $32.05^{\mathrm{b}} \pm 0.024$ & $22.15 \pm 0.034$ & $10.09 \pm 0.037$ & $7.66 \pm 0.034$ \\
\hline $\mathrm{T}_{2}$ & $72 \pm 0.577$ & $28.09^{\mathrm{ab}} \pm 0.020$ & $32.12^{\mathrm{a}} \pm 0.023$ & $22.11 \pm 0.011$ & $10.05 \pm 0.015$ & $7.63 \pm 0.005$ \\
\hline $\mathrm{T}_{3}$ & $73 \pm 1.153$ & $28.14^{\mathrm{a}} \pm 0.010$ & $32.14^{\mathrm{a}} \pm 0.005$ & $22.10 \pm 0.057$ & $10.02 \pm 0.040$ & $7.60 \pm 0.011$ \\
\hline $\mathrm{T}_{4}$ & $73 \pm 0.666$ & $28.15^{\mathrm{a}} \pm 0.030$ & $32.16^{\mathrm{a}} \pm 0.017$ & $22.08 \pm 0.015$ & $10.01 \pm 0.015$ & $7.60 \pm 0.023$ \\
\hline $\mathrm{T}_{5}$ & $73 \pm 1.153$ & $28.15^{\mathrm{a}} \pm 0.015$ & $32.17^{\mathrm{a}} \pm 0.023$ & $22.07 \pm 0.038$ & $10.00 \pm 0.051$ & $7.60 \pm 0.005$ \\
\hline Significant & N.S & $*$ & $*$ & N.S & N.S & N.S \\
\hline
\end{tabular}

* Vertically different letters indicate a significant difference $(\mathrm{P}<0.05)$ between the mean of treatments.

N.S refers to the absence of significant differences (P $<0.05)$ between the mean of treatments.

$\mathrm{T}_{1}$ control treatment $(24 \% \mathrm{SBM}) . \mathrm{T}_{2}(12 \% \mathrm{SBM}+12 \%$ SFM). $\mathrm{T}_{3}(12 \% \mathrm{SBM}+12 \% \mathrm{SM}) . \mathrm{T}_{4}(12 \% \mathrm{SFM}+12 \%$ $\mathrm{SM})$.

$\mathrm{T}_{5}(8 \% \mathrm{SBM}+8 \% \mathrm{SFM}+8 \% \mathrm{SM})$ in starter stage and $\mathrm{T}_{1}(20 \% \mathrm{SBM}), \mathrm{T}_{2}(10 \% \mathrm{SBM}+10 \% \mathrm{SFM}) . \mathrm{T}_{3}(10 \%$ $\mathrm{SBM}+10 \% \mathrm{SM}), \mathrm{T}_{4}(10 \% \mathrm{SFM}+10 \% \mathrm{SM})$ and $\mathrm{T}_{5}(7 \%$ $\mathrm{SBM}+7 \% \mathrm{SFM}+7 \% \mathrm{SM}$ ) in finisher stage

In conclusion there is a possibility to use a combination from sunflower meal, sesame meal and soybean meal as a source of vegetable protein to enhance and improve body weight, growth rate, feed efficiency and main carcass cuts of broiler. This practice reflected positively on overall costs and net return.

\section{References}

[1] Abdul-Abbas .; M.Hassan and Naji , A . H. (2000). The impact of partly and total substitution of sunflower meal which Locally produced as a source of vegetable protein instead of SBM in the productive performance of broiler chickens. J. Agri. Sci. Iraq : Volume 31 Issue (1): 351-360.

[2] Abdul-Abbas, M . H;. Naji . A. H ;. Al-Younis. M And Al-Hassani , Z. H. (2002). Effect of substitution partly or total of sunflower meal subsidized with Lysine instead of SBM in Productive performance to males of mothers of broiler chickens. Iraq. J. Agri. Sci. : Vo( 33) Issue (5): 177-184.

[3] Al-Abode, S. (2014). The use of operations research for the purpose of determining the initially starter diet that used to feed of broiler chickens .. University of Babylon Pure and Applied Sciences Journal, Volume 11 Issue (8): 2219-2232

[4] Al- Azzawi, Y. G. S. (2004). The impact of the use the waste of sesame seeds unfit for the briber manufacture of the some productive traits of broiler chickens. Master Thesis, Faculty of Agriculture and Forestry, University of Mosul, Iraq.

[5] Al- Fayad, H.i Abdel Aziz and Naji, S . AbdulHussein (1989). Technology poultry products, edition First, the Directorate of Higher Education Press, Baghdad

[6] Al-Kassar, A. M. A. (2006). The impact of the use of locally produced protein concentrates, compared with imported Protein concentrates on the productive performance of broiler chickens. $\mathrm{Ph} d$ thesis,
Department of Livestock, Faculty of Agriculture, University of Baghdad

[7] Al- sharabi, Mohamed Mahmoud Khalil (2013). The effect of replacing different levels of sesame meal by Soybeans meal productive some blood parameters of local rabbits . Journal of the Tikrit University of Agriculture. Science. Volume 13 Issue (3), a special issue of the facts of the First International Scientific Conference of the Faculty Agriculture and Veterinary Medicine from 1646 to 1813. ISSN.

[8] Al -Tai, R. Z. Y (2012). The effect of replacement the sputter briber replace the part of the animal protein in diets of broiler chickens. Master Thesis, Faculty of Agriculture and Forestry, University of Mosul, Iraq.

[9] Al-Yaseen, A . Abd al-Khaliq and Abd Al-Abbas, M. H. (2010). Poultry nutrition, the Ministry of Press Higher Education and Scientific Research, Faculty of Agriculture, University of Baghdad.

[10] Al- Yasiri, A . N.;. Abdul Sattar F.; Iyad, S . A. and Mohamed Ib. B.I (2000). Test the locally protein concentrates on the productive performance of broiler Chickens . Iraqi. J. Agri. Sci. , Volume 31 Issue (1): 399403.

[11] Al-Zubaidi, Sohaib Saeed Alwan (1996). Poultry Management, the first edition, Faculty of Agriculture, University of Basra.

[12] A.O.A.C .(2001) . Official Methods of Analysis "17"Ed. Association of official Analysis Chemists . Washington. U.S.A .

[13] Botsoglou ,N.A.; Christaki ,E.;Florou-Paneri , P.; Glannenas ,I.; Papageorgiou ,G. and Spais ,A .B.(2004). The effect of a mixture of herbal essential oils or $\alpha$ - tocopheryl acetate on performance parameters and oxidation of body lipid in broilers . South . Afr . J.Anim . Sci . 34: $52-61$.

[14] Casartelli .E.M.; R.S .Filardi .; O .M. Junqueira .; A. C. Laurentiz .; V. Assuena. And K.F. Daurte(2006). Sunflower meal in commercial layer diets formulated in total and digestible amino acids basis . Barzilian- Journal of Poultry Science. 8:167-171.

[15] Chera-Isarakul, B. and S. Tangtaweewipat (1993). Sesame meal as soybean meal substitute diets Lying hen . AJAS . 6: 253 -258.

[16] Duncan,D.B (1955).Multiple range and multiple " $F "$ test . Biometrics 11(1): 1-42.

[17] Dusterheft ， E.M .; Bonte ,A.W.; Voragen , AGJ.(1992). Solubilization of nonstarch polysaccharides from oil seed meals , by polysaccharides -degrading enzymes .J. Sci Food Agri 63 : 211 -220.

[18] Furian .A. C.; C.Mantovani .; A.E. Murakami.; I.Moreira .; C. Seapinello . and E.N. Martins (2001). 


\section{International Journal of Science and Research (IJSR) ISSN (Online): 2319-7064 \\ Index Copernicus Value (2015): 78.96 | Impact Factor (2015): 6.391}

Use of sunflower meal in feed for broilers .Journal of Animal Science .30: 158 - 164

[19] Gonzalez -Perez,S .(2003). Physico-chemical and Functional properties of sunflower protein . Ph .D. Dissertation Wageningen Univ .The Netherlands, PP.

[20] Ibrahim, Azhar Majid (1999). The effect of replacement waste industry briber replace of part of the animal protein in Diets of broiler chickens. Master Thesis . Faculty of Agriculture and Forestry, Mosul University. Iraq.

[21] Ivanova ， P.; V .Chalova.; L. Koleva . , and IPishtiyski .(2013). Amion acid composition and solubility of proteins isolccted from sunflower meal produced in Bulgaria .Inter .Food Res .J. 20 (6) : 299 -300 .

[22] Kato, M.; Chr .A , and Davin ,L .(1998). Biosynthesis of antioxidant lignins in Sesmum indicum seeds. Phytochemistry. $47: 583$ - 591 .

[23] Khalaf, M. N and Sawsan , M. Abdul Rahman (2015). preparation of Isolated and decaying protein from Sunflower seeds defatted and studying their chemical composition. Iraq. J. Agri. Sci. : Vo( 46) Issue (3): 433-439.

[24] Khawaja, Ali Kadhim;. Alham , Abdullah, and Samir Abdel Wahid (1978) . Chemical composition and nutritional value of material feed Iraqi, a publication of the Department of Nutrition, Livestock Directorate, Ministry of Agriculture And agrarian reform. The Republic of Iraq

[25] Kocher .A.; M. Choct .; M.D. Porter . and J. Broz(2000). The effect of enzyme addition to broiler diets containing high concentrations of Canola or sunflower meal .Poultry Science , 79: 1767 - 1774.

[26] Mamputu ,M. and R .J. Buhr.(1995). Effect of substituting Sesame meal for soybean meal on layer and broiler performance. Poult, Sci . 74 : 672-684.

[27] NaJi , S. Abdul Hussein and Ahmed, A. Abdul Wahid (1985). Poultry production and projects of broiler chickens, the Ministry of Higher Education and Scientific Research, Technical Institutes Foundation

[28] NaJi , S. Abdul Hussein (2006). Commercial production of broiler chickens manual, technical bulletin , 12 , Iraq's Poultry Science association

[29] Olimpia .Colibar.(2006). The use of soybean in broiler feed formulas bulletin Usamv- en 63: 57-62.

[30] Oshodi , A.; Ogunghenle ,H . and Oladimji , M (1999). Chemical composition, nutritionally valuable minerals and functional properties of benni seed Sesamum radiatum, pearl millt Pennisetum typhoids and quinon Chenopodium quiona flours . Int .J. Food .Sci .Nutr . 50 (5) : $325-331$.

[31] Pinheiro ,J.W.; N.A.N. Fonseca.; C.A. Silva .; L. Cabrera ; F.A.T. Bruneli and S.E. Takahashi,(2002). Sunflower meal in feed for broiler chickens at different stages of development . Journal of Animal Science , 31: 1418 - 1425.

[32] Rama .Rao ,S. V.; Mr .L. N. Rajn .; A .K .Panda .;N .S. Poonam .; G. Shayam Sunder . and R .P. Sharm (2008).Ultiation of sesame (sesamum indicum) seed meal in broiler chicken diets . British Poultry Science . 49(1): $81-85$.
[33] Salari ,S.; H.Nassiri Moghaddam.; J. Arshaml . and A.Gollan (2009). Nutrition evaluation of full- fat Sunflower seed for broiler chickens .Asian - Aust .J. Anim .Sci. Vol 22 . No (4): 557 - 564.

[34] San Juan, L.D. and M.J. Villamide (2001). Nutritional evaluation of sunflower products for poultry as affected by the oil extraction method . Poultry Science . $80: 431-$ 437.

[35] Senkoylu , N. and N. Dale.(2006). Nutrition evaluation of a high -oil sunflower meal in broiler starter diets . Journal of Applied Poultry Research , 15: 40 - 47

[36] Sen , M .and Bhattacharyya. (2001). Nutritional quality of Sesame seed protein fraction extracted with Isoproanol. J. Agri .F. Chem . $49: 2641-2646$.

[37]Serman , V.; N. MAS, V.; V. Melenjuk .; F. Dumanouski . and Z. Mikulec (1997). Use of sunflower meal in feed mixtures for laying hens, Acta Vet Brno. 66 $: 219-227$.

[38] Shahidi, F.; Janitha, P . and Wanasundera , P .( 1992). Phenolic antioxidants, critical review in Food Science and Nutrition . $32: 67-103$.

[39] Shams Al- din, Q. . Z. I. ; Al-Rawi .A. Abdul Hamid ; Mohamed . H and Salh, M . H. (2002). The effect of replacement of the nigela Sativa meal in the diets broiler chickens on the productive performance. VIII Scientific Conference to the body of commission technical education.

[40] Sobh , A. M ;. A. Al - Samman and F. Sultan (2012). The impact of use the sunflower meal instead of soybean meal in the diets of carps fish on the production efficiency, Journal -Baath University: Vol (34) . No (31).

[41]SPSS (2008). Statistical Package for Social Sciences, $\mathrm{V}, 13$

[42] Swick ,R .A.; Akiyama , D .M .; Boonyaraatpalin . M . and Creswell .D.C .(1995). Use of soybean meal and sxnthetic methionine in shrimp feed. American Soybean Association, Technical Bulietin . 